\title{
Suitability of Ground Water in Southwest Kirkuk for Human Consumptions
}

\author{
Rodhan A. Salih, Abdulrazaq K. Abdulwahd*, Fadya A. Sulaiman \\ Department of technical water resource, Al-Hawija technical institute, Northen Technical University, Iraq \\ *corresponding author email: abd.kder@yahoo.com
}

\begin{abstract}
Groundwater is one of the important sources of providing the human with water for drinking and other purposes. In Iraq, most of the agricultural land far from surface water sources, which forced these farmers to use groundwater wells as a source to cover the needs of the water and uses for different household. Furthermore, in some areas of Iraq, the available surface water that is suitable for human consumption is insufficient. Hence, the ground water is the viable solution to provide drinking water. The aim of this study is to show the extent validity of the ground water for various human uses.Twenty wells were chosen at different location in the southwest of Kirkuk city. Physical and chemical tests were carried for each water samples which include nitritenitrogen, phosphate, total hardness as $\mathrm{CaCo}_{3}$, total dissolved solids, chloride, $\mathrm{PH}$, and turbidity. The results were evaluated and compared accordingly with World Health Organization (WHO) specifications. The results showed that the ground water in the study areas not suitable for drinking because of the contamination with Nitrite - nitrogen, phosphate and high contents of total hardness and TDS.
\end{abstract}

Keywords:grawndwater,sutibality, consuption

Paper History: Received: 17/10/2017; Accepted: $18 / 3 / 2018$

\section{1- Introduction}

Groundwater is considered an important source of water supply for humans to meet different needs. The demanding for this source of water increases due to the continuing growth in the number of population, Water from wells were not suitable for human consumption according to WHO standards [1]. The quality of drinking water is very important for public health and prosperity. The successive drought years, as well as the lack of availability of surface water in most places, pay the human to depend on groundwater as a source for water supplied.

S.Adnan and J.Iqbal [2] investigated the assessment of groundwater quality by examining some of the chemical and physical properties of the aquifer area of Peshawar, Pakistan.The measured properties include; PH, EC, TDS, T.H, Alkaline, Ca, $\mathrm{Mg}$, Turbidity,Nitrate and Chloride.The study results show increased concentrations of the investigated characteristics except for nitrates and $\mathrm{PH}$ in the city center.

M. Dhanasekarapandian et al. [3] studied (29) sample of groundwater to determine their suitability for human consumption and they show exceeded specifications for the limits permitted by WHO.

One of the biggest problems of the developing countries is the pollution of groundwater with various sources of pollution, whether through the raceways, or throw waste or the use of pesticides and agricultural fertilizers or soil which makes them unsuitable for human use.

In this research extensive study has been aims to evaluate the different characteristics of the groundwater for the area southwest of Kirkuk operated by the population of farmers and some of them live in agricultural land owned. Most of the agricultural land far from surface water sources, which forced these farmers to use groundwater wells as a source to cover the needs of the water and uses different household. This study aims to show the extent validity of the water in these areas for various human uses.

\section{2-Methods and Materials}

Twenty wells were selected from different locations; Figures (1) and (2). All of these wells were digging by farmers in order to use them as a source of water for domestic use. Water suction from these wells is preformed by pumps powered by electricity or diesel engines. Deep wells ranged between (20-50) meters. Samples were taken by running the pumps operating on wells for (5-10) minutes and then took the samples which stored in glass bottles according the samples requirements [4]. Chemical and physical tests were conducted and repeated many times for different water samples. Therefore the average of four tests for each property was considered for more accurate results .Micro 100 IR Turbidity meter has been used to measure turbidity and the remote Multi Parameter PCS Tester Tm 3sto measure the concentration of each of the $\mathrm{PH}$ and total dissolved solids and nitrates. The concentrations of total hardness and chloride were measured by titration. The program (GIS) has been used to represent the chemical and physical properties in the form of maps of the wells under study by S.Venkateswarana and 
S.Deepaa[5] the results were compared with World Health Organization standards(WHO)[6].

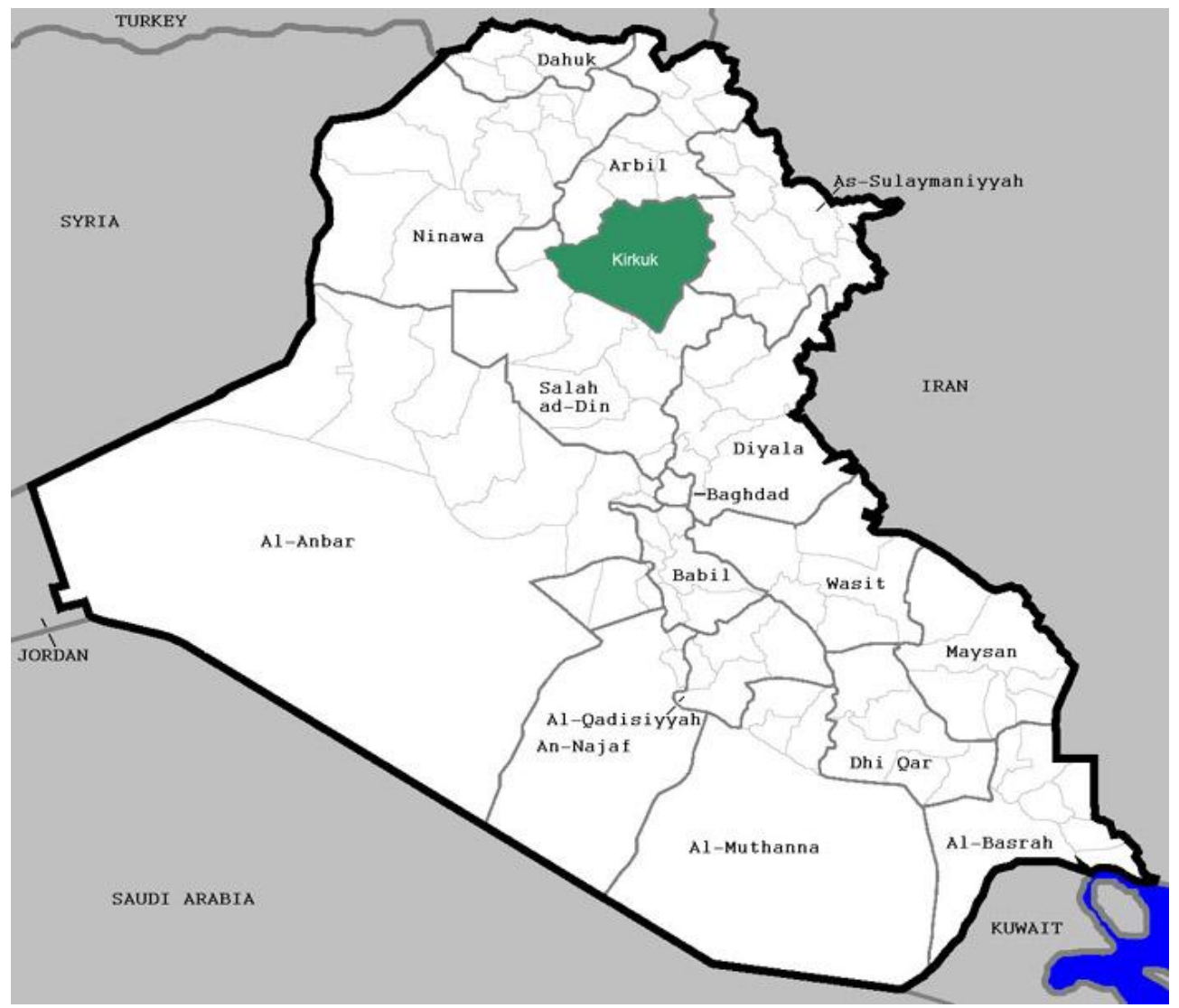

Figure (1) The map of Iraq reveals by the province of Kirkuk site

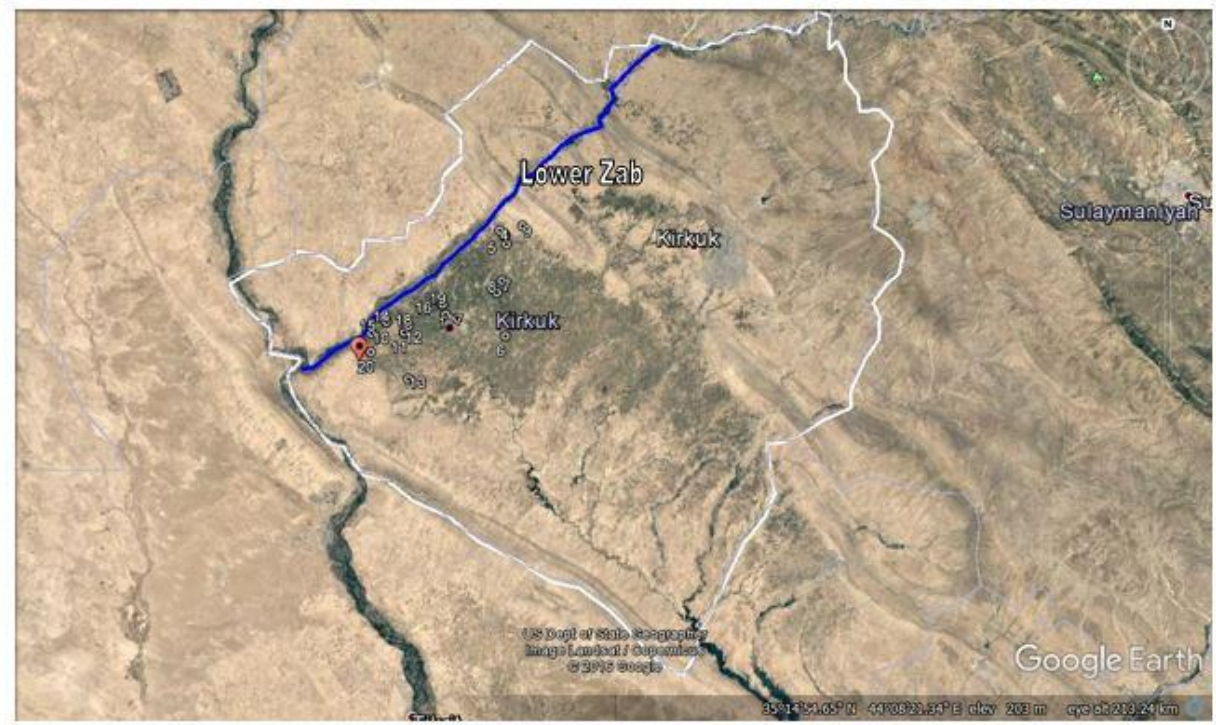

Figure (2) A map of the wells of study area

\subsection{Statistical analysis}

SPSS software was used to find the correlation between the chemical and physical properties investigated in this study. The statistical analysis also used to explained that the TDS value is directly proportional affected with both TH (0.54) and PO4 (0.537) and the rest of the properties that have been studied with little effect on ( TDS) as listed in Table 1 . 
Table 1 the statistical analysis of the chemical and physical properties of the wells

\begin{tabular}{|c|c|c|c|c|c|c|c|}
\hline & NO3 & PO4 & CL & Turbidity & PH & T.H & TDS \\
\hline NO3 & 1 & & & & & & \\
\hline PO4 & 0.132 & 1 & & & & & \\
\hline CL & -0.040 & -0.157 & 1 & & & & \\
\hline Turbidity & 0.172 & -0.235 & 0.110 & 1 & & & \\
\hline PH & 0.311 & 0.281 & 0.238 & 0.200 & 1 & & \\
\hline T.H & -0.069 & 0.380 & 0.013 & -0.284 & 0.001 & 1 & 1 \\
\hline TDS & -0.075 & 0.537 & 0.008 & -0.023 & -0.166 & 0.540 & 1 \\
\hline
\end{tabular}

\section{3-Results and discussion}

To assess the suitability of groundwater for human consumption, various tests for the property characterization of the ground water were conducted and the results listed in Table 2 and Figures (3-9).
They compared the results with the allowable limits according to the international standard (WHO). The results showed a wide variation in the values of the properties studied as follows:

Table 2 represents the values of average properties of studied groundwater wells

\begin{tabular}{|c|c|c|c|c|c|c|c|c|c|}
\hline \multirow{2}{*}{$\begin{array}{c}\text { Wells } \\
\text { No }\end{array}$} & \multicolumn{2}{|c|}{ World coordinate } & \multirow{2}{*}{$\begin{array}{c}\mathrm{NO}_{3} \\
\mathrm{Mg} / \mathrm{L}\end{array}$} & \multirow{2}{*}{$\begin{array}{c}\mathrm{PO}_{4} \\
\mathrm{Mg} / \mathrm{L}\end{array}$} & \multirow{2}{*}{$\begin{array}{c}\mathrm{CL} \\
\mathrm{Mg} / \mathrm{L}\end{array}$} & \multirow{2}{*}{$\begin{array}{c}\text { Turbidity } \\
\text { (NTU) }\end{array}$} & \multirow{2}{*}{$\mathrm{PH}$} & \multirow{2}{*}{$\begin{array}{l}\text { TDS } \\
\mathrm{Mg} / \mathrm{L}\end{array}$} & \multirow{2}{*}{$\begin{array}{r}\mathrm{T} . \mathrm{H} \\
\mathrm{Mg} / \mathrm{L}\end{array}$} \\
\hline & $\mathrm{N}^{\mathrm{o}}$ & $\mathrm{E}^{\mathrm{o}}$ & & & & & & & \\
\hline 1 & 352008 & 434706 & 17.8 & 2.19 & 45.25 & 2.4 & 7.3 & 1881 & 1440 \\
\hline 2 & 352914 & 435332 & 14.9 & 2.33 & 225.5 & 2.74 & 7.9 & 1391 & 1200 \\
\hline 3 & 352922 & 435336 & 8.6 & 2.29 & 47.2 & 2 & 7.3 & 2630 & 1180 \\
\hline 4 & 352948 & 435254 & 8.5 & 2.22 & 282.5 & 1.7 & 7.8 & 2612 & 1140 \\
\hline 5 & 352817 & 435348 & 9.3 & 2.36 & 20.7 & 2.23 & 7.75 & 1195 & 1020 \\
\hline 6 & 351811 & 435340 & 4.8 & 2.29 & 220.7 & 3 & 7.2 & 1375 & 1940 \\
\hline 7 & 352418 & 435311 & 9.7 & 1.85 & 207.1 & 2 & 7.1 & 1350 & 1180 \\
\hline 8 & 352258 & 435231 & 4.7 & 2.26 & 132.6 & 3.5 & 7.2 & 1753 & 1580 \\
\hline 9 & 353018 & 435558 & 4.4 & 1.88 & 58.8 & 2.69 & 7.34 & 1102 & 850 \\
\hline 10 & 351830 & 433534 & 18 & 1.85 & 90.8 & 5.1 & 7.5 & 1005 & 900 \\
\hline 11 & 351834 & 434000 & 18.6 & 2.9 & 51.6 & 1.53 & 7.45 & 1776 & 1680 \\
\hline 12 & 351835 & 434000 & 7.3 & 2.32 & 37.9 & 1.82 & 7.1 & 1777 & 1740 \\
\hline 13 & 351928 & 434033 & 4.5 & 2.31 & 28.3 & 1 & 6.96 & 1923 & 1311 \\
\hline 14 & 351941 & 433735 & 9.8 & 1.91 & 23.5 & 2 & 6.93 & 1928 & 1450 \\
\hline 15 & 351945 & 433738 & 9.8 & 2.28 & 45.3 & 1.96 & 7.2 & 1831 & 1350 \\
\hline 16 & 352143 & 434506 & 6.8 & 2.33 & 47.9 & 2.39 & 7.8 & 1341 & 1215 \\
\hline 17 & 352034 & 434534 & 8.6 & 2.62 & 48.1 & 3.79 & 7.7 & 2580 & 2000 \\
\hline 18 & 351918 & 434033 & 8.2 & 2.37 & 116.2 & 2.64 & 7.1 & 2538 & 2100 \\
\hline 19 & 352141 & 434510 & 8.2 & 2.21 & 92 & 2.55 & 7.2 & 1145 & 970 \\
\hline 20 & 351625 & 433529 & 6.9 & 2.25 & 95.3 & 3 & 6.9 & 1300 & 1050 \\
\hline WHO & & & 50 & 2 & 250 & 5 & $6.5-8$ & 1500 & 500 \\
\hline
\end{tabular}




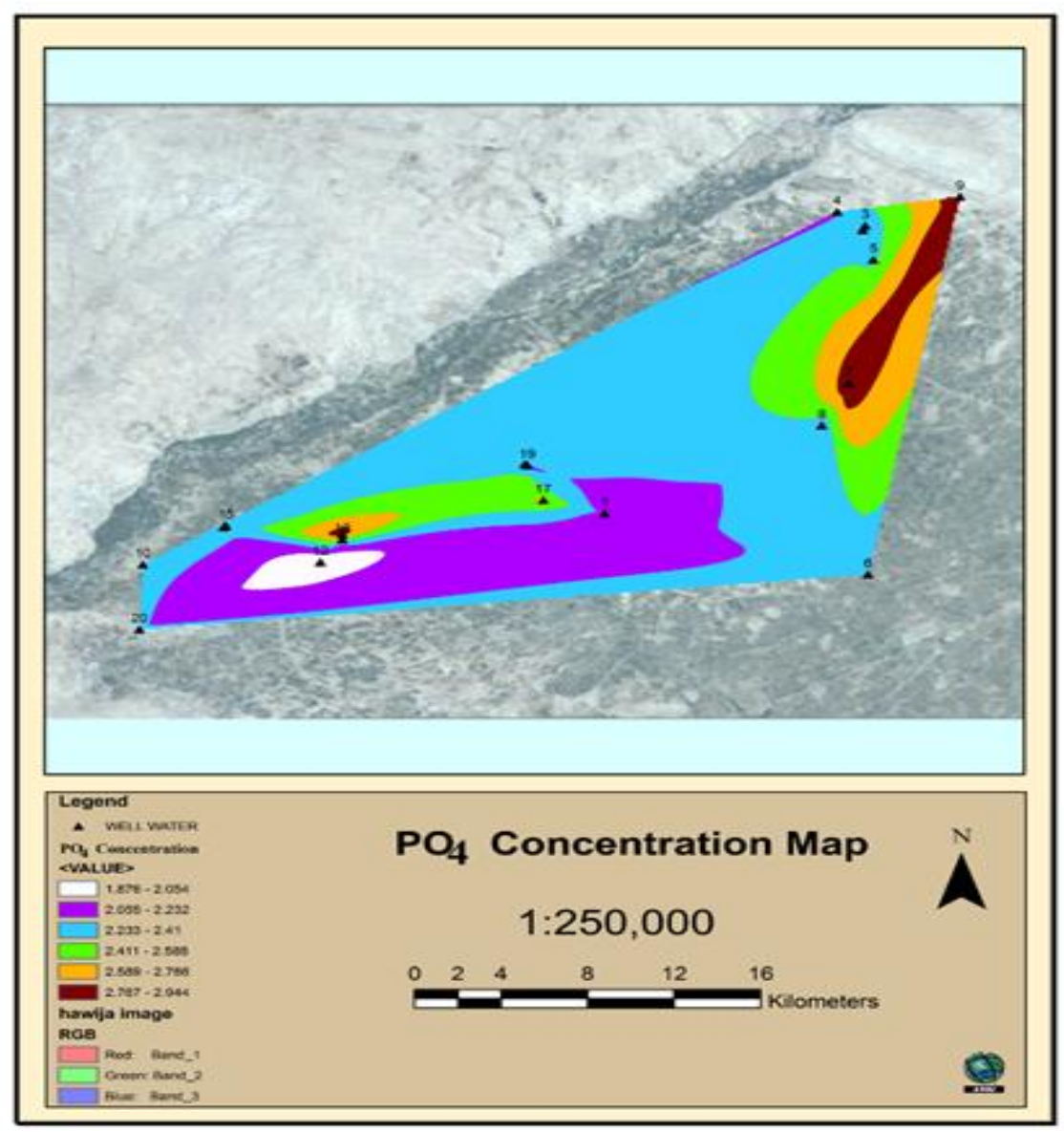

Fig.(3) Nitrat concentration map

\subsection{Nitrates:(NO3)}

Figure (3) shows that the wells $(1,2,10,11)$ with high concentrations of nitrate nitrogen as well as the case of the wells $(7,14,15)$ because of wells are located in agricultural areas. The farmers use the fertilizer and pesticides to combat plantings, due to agricultural activities [7]. Nitrates have a negative 3.2 Phosphates: $\left(\mathrm{PO}_{4}\right)$

Figure (4) showed that high concentrations of phosphate for all wells, except wells $(7,9,10,14)$ and this is due to the use of farmers phosphate fertilizer compound. the lack of sewage systems in villages, throw waste cleaning and sewage near the wells impact, particularly on fetuses at the age of three months [8]. The remaining wells showed varying concentrations of nitrate but within limits of WHO. Well No. (9) low concentration record for being located in near the Lower Zab river and are fed from the river water, resulting in a reduced the concentration of nitrates .

increasing the concentrations of phosphate. The high value of the concentrationis record well (11) while the less value are record in wells $(7,10)$. The concentration of (9) within the permissible limited of WHO. 


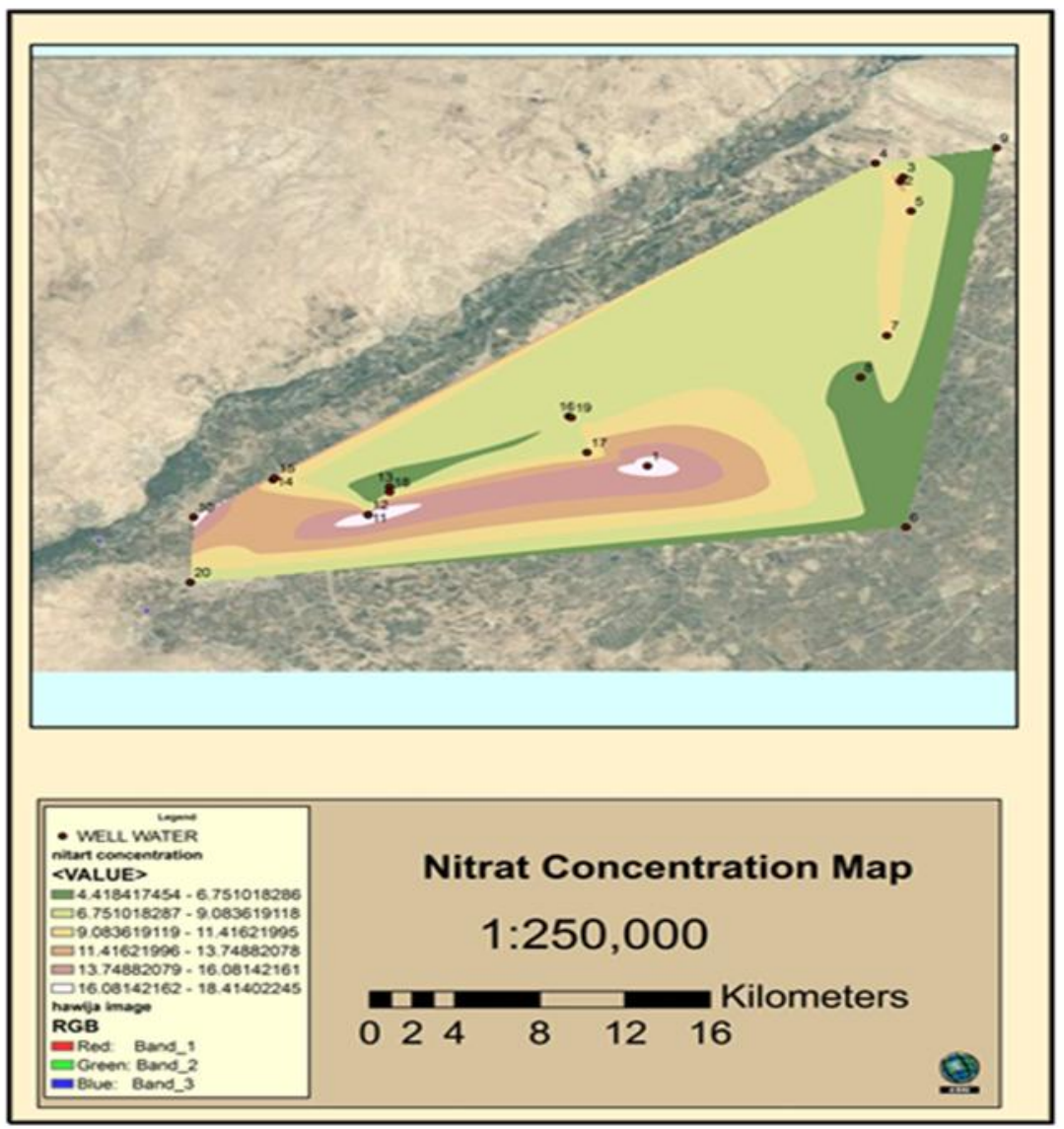

Fig. ( 4 ) $\mathrm{PO}_{4}$ concentration Map

\subsection{Chloride:(CL)}

Figure (5) represents chloride values for wells. The concentrations of all wells are within the allowable limits, except for the well (4). Well (4) is located near Almahooz village and the leakage of sewage water into the ground water causes a high chloride ratio

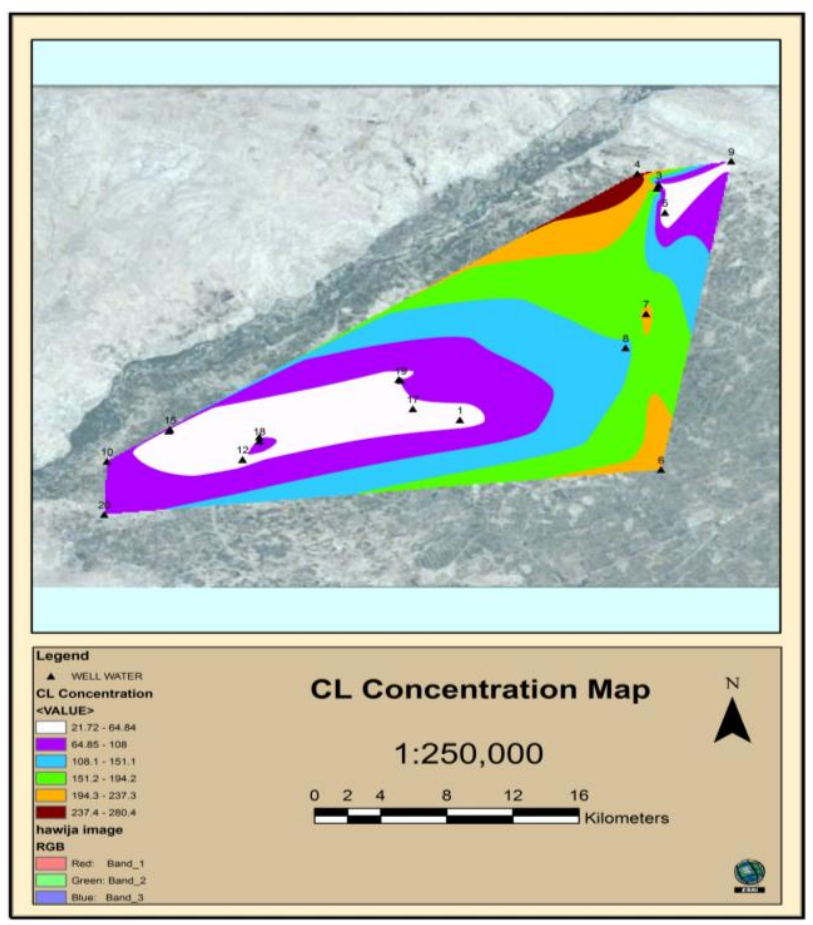




\subsection{Turbidity}

Figure.( 5 ) CL concentration Map

Figure (6) shows that the average turbidity of all wells within the permissible limit values due to leaching property that characterize groundwater

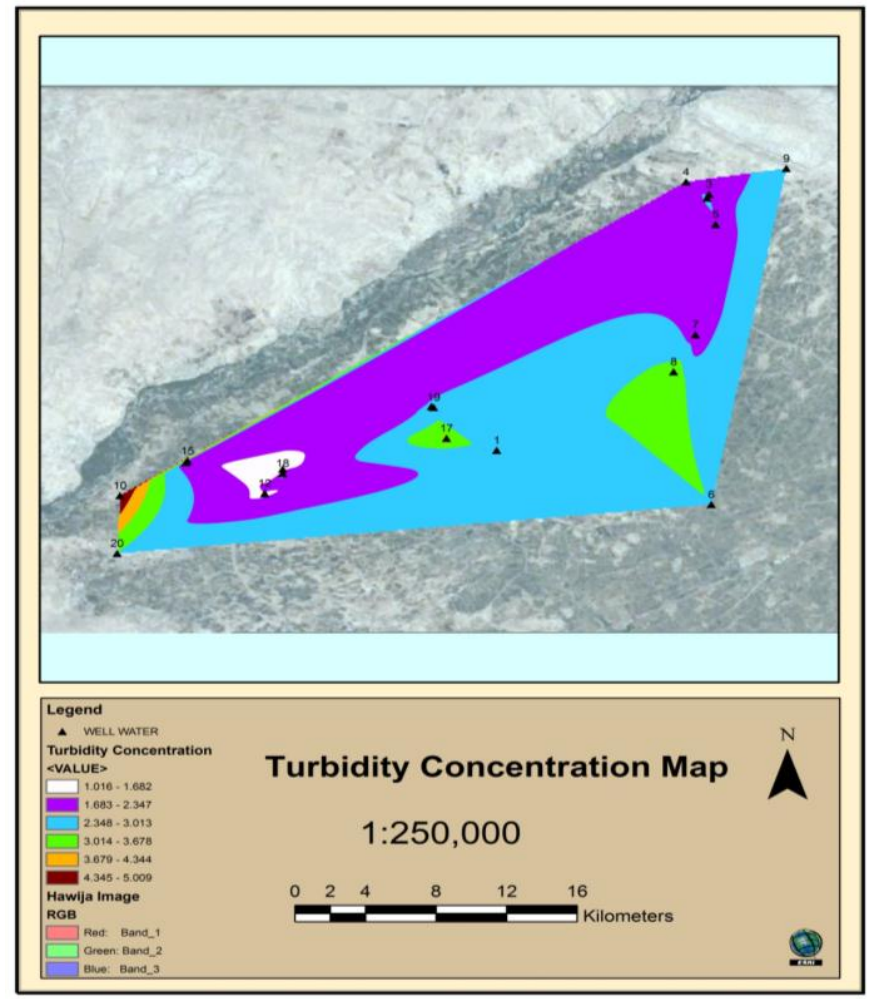

Fig.( 6 ) Turbidity concentration Map

\subsection{PH:} 7.81)

Figure (7) shows the concentration $(\mathrm{PH})$ for all wells are within the allowable limits, ranged between (6.9-

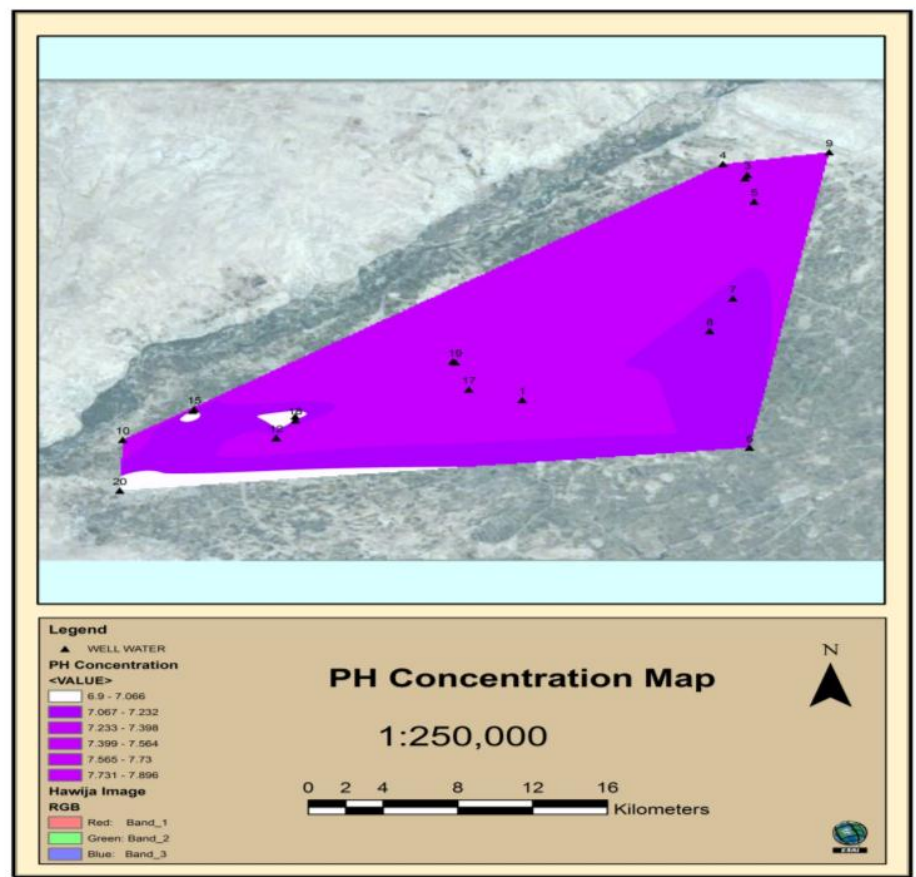

Fig.( 7 ) PH concentration Map 


\subsection{Total dissolved solids (TDS)}

Figure (8) shows the concentrations of total dissolved solids. Most wells have recorded an increase in the concentrations of total dissolved solids permitted except for wells $(2,5,6,7,9,10,16,19$, 20) making it unsuitable for use

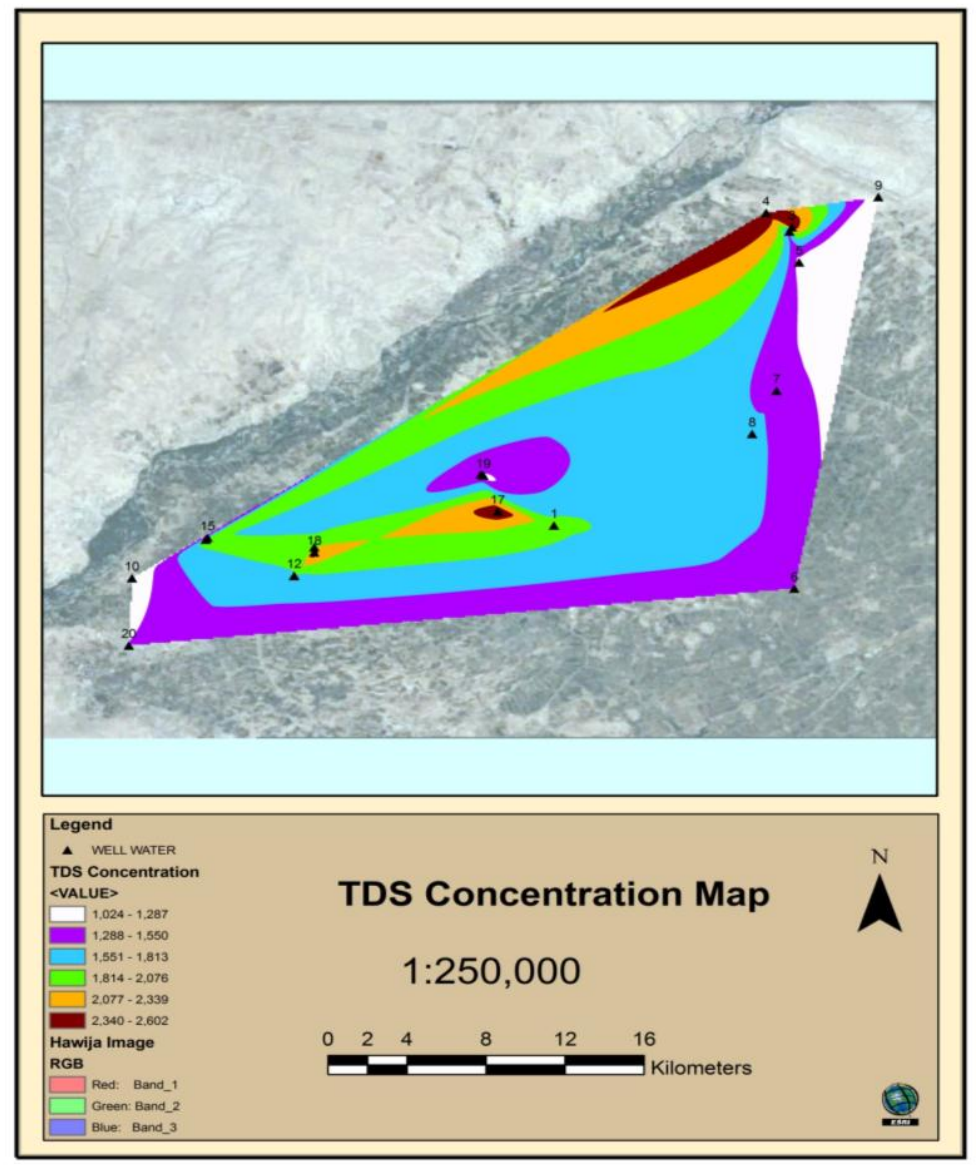

Fig.( 8 ) PH concentration Map

\subsection{Total hardness (T.H)}

Figure (9) shows the Total hardness. All wells exceeded the allowable limits and recorded high values and are classified as highly hardness, because of the soil quality. The use of hard water may cause taste undesirable, intestinal disorders [9], increasing soap consumption and closes the pores of the human skin. The use of hard water in the tissue industry, paper and packaging may lead to a decline in the quality of production and the use of hard water for boiler be seale and caused the loss in heat transfer. 


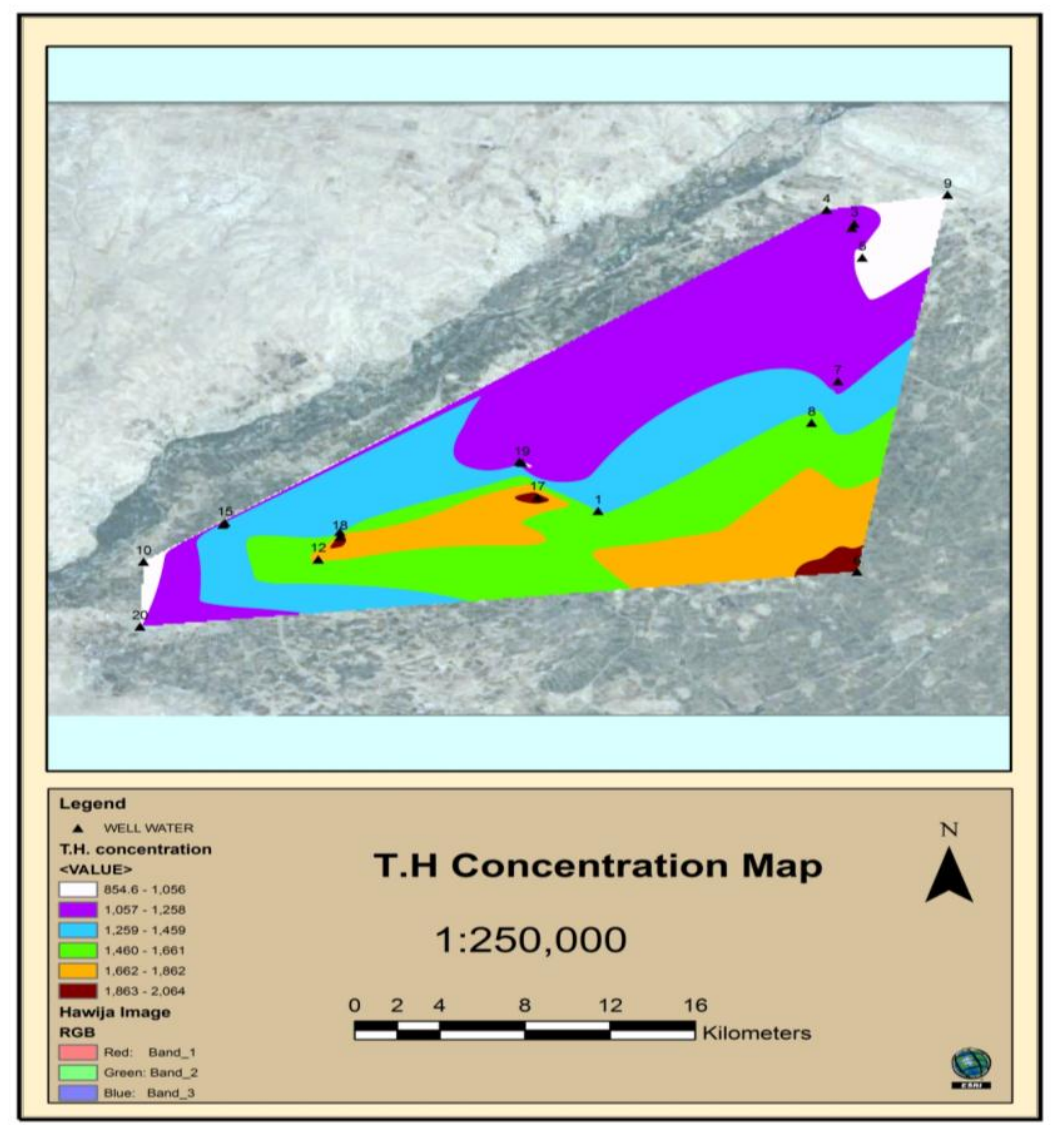

Fig.(9) T.H concentration map

\section{4- Conclusions}

$1-35 \%$ of the wells showed a high concentration of nitrates.

$2-80 \%$ of the wells showed a high concentration of phosphate.

3. All wells are characterized low turbidity, making it suitable for cleaning and washing.

4. All wells are classified as high salt content and highly hardness, making them unsuitable for household uses, especially drinking.

5. Well No. (9) is suitable for drinking and within specifications of WHO.

6- The results of the statistical analysis (SPSS) show that the concentration of TDS is significantly affected by concentrations of T.H and $\mathrm{PO}_{4}$.

\section{5- Recommendations}

1. Water wells does not suitable for drinking because the high concentration of nitrate and TDS.

2. Well No.(9) is excluding from the recommendation (1) above because the well within the specification limits of WHO .

3. We recommend a bacteriological examination of the well (9) for its safety from bacterial contamination before use for human consumption .

\section{References}

[1] Wuta, M., G. Nyamadzawo, J. Mlambo, and P. Nyamugafata. 2015. "Ground and Surface Water Quality along a Dambo Transect in Chihota Smallholder Farming Area, Marondera District, Zimbabwe." Physics and Chemistry of the Earth 92 (2016):112-18. https://doi.org/10.1016/j.pce.2015.09.014.

[2] Adnan, S., and J. Iqbal. 2014. "Spatial Analysis of the Groundwater Quality in the Peshawar District, Pakistan." Procedia Engineering 70:1422. https://doi.org/10.1016/j.proeng.2014.02.003.

[3] .Dhanasekarapandian, M., S. Chandran, D. Saranya Devi, and V. Kumar. 2016. "Spatial and Temporal Variation of Groundwater Quality And??its??suitability for Irrigation and Drinking Purpose Using GIS and WQI in an Urban Fringe." Journal of African Earth Sciences 124 (2016):270-88. https://doi.org/10.1016/j.jafrearsci.2016.08.015.

[4] .Association, American Public Health. 1975. Standard Methods for the Examination of Water and Wastewater. 14thed.

[5] .Venkateswaran, S., and S. Deepa. 2015. "Assessment of Groundwater Quality Using GIS Techniques in Vaniyar Watershed, Ponnaiyar River, Tamil Nadu." Aquatic Procedia 4 (Icwrcoe):1283-90. https://doi.org/10.1016/j.aqpro.2015.02.167.

[6] .WHO. 2008. "Guide for Drinking Water Quality." Vol , 1 Geneva. 
[7] .Zaidi, Faisal K., Saad Mogren, Manoj Mukhopadhyay, and Elkhedr Ibrahim. 2016. "Evaluation of Groundwater Chemistry and Its Impact on Drinking and Irrigation Water Quality in the Eastern Part of the Central Arabian Graben and Trough System, Saudi Arabia." Journal of African Earth Sciences 120 (2016):208-19. https://doi.org/10.1016/j.jafrearsci.2016.05.012.

[8] .Sadler, Ross, Brooke Maetam, Benjamin Edokpolo, Des Connell, Jimmy Yu, Donald Stewart, M. J. Park, Darren Gray, and Budi
Laksono. 2016. "Health Risk Assessment for Exposure to Nitrate in Drinking Water from Village Wells in Semarang, Indonesia." Environmental Pollution 216:738-45. https://doi.org/10.1016/j.envpol.2016.06.041.

[9] Montgomery, J.M. 1985. Water Treatment Principles and Design. John Wiley and Sons. 